\title{
Bisalbuminämie
}

\section{Nur eine Laune der Natur?}

— Die Serum-Eiweißelektrophorese eines 28-jährigen Mannes zeigt einen Extragradienten im Bereich des Albumins, der auch auf der Zelluloseacetatfolie erkennbar ist (Abb. 1). Das aus der Elektrophorese und dem Gesamteiweiß errechnete Albumin liegt bei Zusammenfassung des Doppel-Peaks bei 50,0 g/l (Referenzbereich 35,2-50,4 g/l), das chemisch direkt bestimmte Albumin übereinstimmend bei 53,2 g/l. Dies legt nahe, dass die Extrabande Albumin entspricht.

Die Sequenzierung des Albumingens ergibt die heterozygote Mutation c.1789A $>$ G, p.Lys597Glu (Albumin Ghent/Milano fast), eine von etwa 65 Mutationen im Albumingen, die zu einer Bisalbuminämie (auch Albumin-Allomorphie) führen. Die Vererbung erfolgt autosomal-kodominant, sodass Heterozygote normales und variantes Albumin synthetisieren. Da die Laufzeiten unterschiedlich sind, zeigen sich zwei Albumingipfel in der Elektrophorese.

\section{Meist ohne Krankheitswert}

Die Häufigkeit von Albuminvarianten liegt in der Allgemeinbevölkerung bei etwa 1:1.000, kann allerdings in bestimmten Populationen wie abgeschieden lebenden südamerikanischen indigenen Stämmen deutlich höher sein. Trotz teilweise verändertem Bindungsverhalten für z.B. Spurenelemente, Schilddrüsenhormone oder Medikamente sind Albuminvarianten normalerweise ohne Krankheitswert.

\section{$\rightarrow$ Anschrift des Verfassers:}

Dr. med. Bernd Maire

Labor Dr. Staber \& Kollegen

Sülmer Straße 60, D-74072 Heilbronn

E-Mail: b.maire@labor-staber.de
Hier steht eine Anzeige.

Springer

\section{Abb. 1 Befund in der Elektrophorese und auf der Zelluloseacetatfolie}

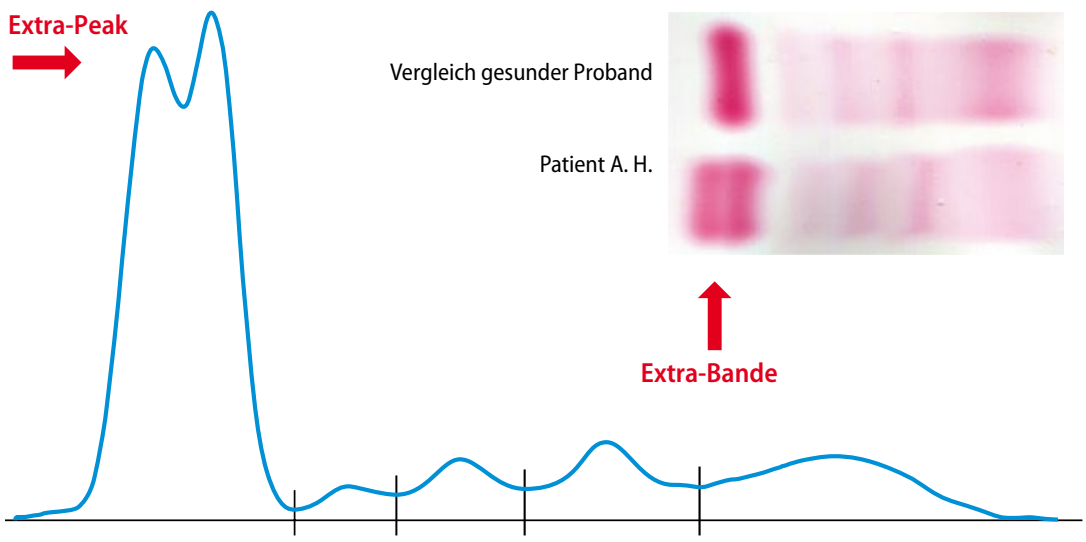

